\title{
Tungstophosphoric acid supported onto hydrous zirconia: Physicochemical characterization and esterification of $1^{\circ}$ and $2^{\circ}$ alcohol
}

\author{
PANKAJ SHARMA and ANJALI PATEL* \\ Chemistry Department, Faculty of Science, M.S. University of Baroda, Vadodara 390 002, India
}

MS received 15 September 2005; revised 11 July 2006

\begin{abstract}
The Keggin type heteropolyacid, 12-tungstophosphoric acid (PW), was supported onto hydrous zirconia $(\mathrm{Z})$ by impregnation method and designated as $\mathrm{ZH}_{3}$. The $\mathrm{ZH}_{3}$ was calcinated at $300^{\circ} \mathrm{C}$ and $500^{\circ} \mathrm{C}$ and designated as $\mathbf{Z H}_{33}$ and $\mathrm{ZH}_{35}$, respectively. The resulting materials were characterized by FTIR, diffuse reflectance spectroscopy (DRS), XRD, surface area measurement (BET method) and particle size distribution. The surface morphology was studied by scanning electron microscopy. The acidity of all materials was evaluated by carrying out chemisorption of ammonia and esterification of $1^{\circ}$ alcohol ( $n$-butanol) with different acids like formic acid, acetic acid and propionic acid and $2^{\circ}$ alcohol (cyclohexanol, iso-butanol) with acetic acid. Above studies show the high dispersion of HPA in a non-crystalline form on the support as well as uniform distribution of particles of $\mathrm{ZH}_{3}$ which contains 30\% 12-tungstophosphoric acid. It also shows that when $\mathrm{ZH}_{3}$ was calcinated at $500^{\circ} \mathrm{C}$, it possesses highest acidity for both chemisorption of $\mathrm{NH}_{3}$ as well as esterification reactions.
\end{abstract}

Keywords. Hydrous zirconia; heteropolyacid; morphology; particle size; acidity.

\section{Introduction}

Catalysis by heteropolyacids (HPAs) of the Keggin's structure is one of the most important and growing areas of research in recent years. They have been used in both homogeneous and heterogeneous catalysis (Misono et al 1982; Izumi et al 1983; Misono and Nojiri 1990; Hill and Posser-McCarthy 1995; Kozhevnikov et al 1995; Blasco et al 1998; Chu et al 1998; Mizuno and Misono 1998). The importance, characterization and properties of various HPAs have been reviewed in the literature (Misono 1987; Kozhevnikov 1995; Okuhara et al 1996). They are better active catalysts for various reactions in solution than conventional mineral acids (Kozhevnikov and Matveev 1983; Kozhevnikov 1987, 1994, 1995; Izumi et al 1992; Okuhara et al 1994, 1996; Wu et al 1996). The main disadvantage of HPAs lies in their low efficiency due to low surface area, rapid deactivation and poor stability. Furthermore, they suffer from the same traditional problem of separation from the reaction mixture when used in polar solvents.

Supporting of HPAs onto suitable support can overcome/ improve the above mentioned disadvantages. The support provides an opportunity for HPAs to be dispersed over a large surface area. A variety of supports such as silica (Rocchiccioli-Deltcheff et al 1990; Nowinska et al 1991;

\footnotetext{
*Author for correspondence (aupatel_chem@yahoo.com)
}

Schwegler et al 1992; Swanml et al 1997; Tatibouet et al 1997; Faming et al 1998; Misono 1998; Pizzio et al 1998; $\mathrm{Hu}$ et al 1999; Molnar et al 1999; Vazquez et al 1999; Choi et al 2000; Dutenhefner et al 2001; Kozhevnikov et al 2001; Gao and Moffat 2002; Bielanski et al 2003a,b; Damyanova et al 2003; Haber et al 2003; Ivanov et al 2003; Okuhara 2003; Pizzio et al 2003), alumina (Wu et al 1996; Hu et al 1999; Vazquez et al 1999; Bielanski et al 2003a,b; Pizzio et al 2003), titania (Wu et al 1996; Damyanova and Fierro 1998; Pizzio et al 1998; Knifton and Edwards 1999; Vazquez et al 1999; Bielanski et al 2003a, b), carbon (Izumi et al 1983; Schwegler et al 1990, 1992; Dupont et al 1995; Dupont and Lefebve 1996; Wu et al 1996; Pizzio et al 1998, 2003; Mukai et al 2003), MCM-41 (Blasco et al 1998; Verhoef et al 1999; Siahkali et al 2000; Jalil et al 2001; Nowinska et al 2003), acidic ion exchange resins (Nomiya et al 1986; Ivanov et al 2003) and clay (Wu et al 1996; Yadav and Bokade 1996; Yadav and Kirthivasan 1997; Knifton and Edwards 1999; Yadav et al 1999; Yadav and Doshi 2000, 2002) have been used for supporting HPAs and different reactions have been carried out. Supported HPAs have a number of advantages like high catalytic activity and selectivity, possibility of their repeated use, easy separation from reaction mixture, high surface area, high thermal stability and most of all there is no problem in the disposal of used catalyst. Since the supported catalysts are more active than the unsupported ones, it is important to understand the nature of interaction between the HPA and the supports. These interactions 
depend on the central and addenda atom of heteropolyanion, loading as well as dispersion of heteropolyacid onto the support, nature of the support and pre-treatment (Clark et al 1992). The difference in the performance of the supported catalyst can be explained by considering the change in acidity.

Various methods such as titration with hammet indicators, temperature-programme desorption (TPD), adsorption microcalorimetry, catalyst probe reactions and NMR have been used to probe solid acidity. A commonly used technique to study solid acidity is TPD of adsorbed bases such as $\mathrm{NH}_{3}$ or pyridine. The catalytic performance can also be used to rank solid acidity.

In the previous paper (Patel et al 2003), a series of catalysts containing 12-tungstophosphoric acid and hydrous zirconia were synthesized and characterized in detail. It was found that the species present on hydrous zirconia was the heteropolyanion, $\left[\mathrm{PW}_{12} \mathrm{O}_{40}\right]^{3-}$, with undegraded keggin structure. Based on all studies, the catalyst containing 30\% 12-tungstophosphoric acid supported onto hydrous zirconia $\left(\mathrm{ZH}_{3}\right)$ was found to be the best. The objective of this paper is to study the effect of temperature (calcination) on the supported keggin structure, alternation of surface of the support, particle size distribution and acidity.

In the present paper, the calcination of $\mathrm{ZH}_{3}$ was carried out at two different temperatures, $300^{\circ} \mathrm{C}$ and $500^{\circ} \mathrm{C}$ and catalysts were designated as $\mathrm{ZH}_{33}$ and $\mathrm{ZH}_{35}$, respectively. All materials were characterized for chemical stability, FTIR, DRS, XRD, surface area measurement (BET method) and particle size distribution. The surface morphology was studied by scanning electron microscopy (SEM). The acidity of all materials was determined by chemisorption of ammonia as well as by evaluating the catalytic activity for esterification of $1^{\circ}$ alcohol ( $n$-butanol) with different acids like formic acid, acetic acid and propionic acid and of $2^{\circ}$ alcohols (cyclohexanol and isobutanol) with acetic acid. Among them $\mathrm{ZH}_{35}$ was found to be the best catalyst with maximum acidity.

\section{Experimental}

\subsection{Materials}

All chemicals used were of A.R. grade. $\mathrm{H}_{3} \mathrm{PW}_{12} \mathrm{O}_{40} \cdot n \mathrm{H}_{2} \mathrm{O}$ and $\mathrm{ZrOCl}_{2} \cdot 8 \mathrm{H}_{2} \mathrm{O}$ (Lobachemie, Mumbai) were used as received. $n$-Butanol, cyclohexanol, iso-butanol, formic acid, acetic acid, propionic acid and ascorbic acid were obtained from E. Merck, Mumbai and used as received.

\subsection{Synthesis of catalyst}

The hydrous zirconia support was synthesized by the method reported earlier (Patel et al 2003). Catalyst containing $30 \%$ 12-tungstophosphoric acid (PW) was synthesized by impregnating $1 \mathrm{~g}$ of hydrous zirconia with an aqueous solution of PW $(0 \cdot 3 \mathrm{~g} / 30 \mathrm{ml}$ of conductivity water) followed by drying at $100^{\circ} \mathrm{C}$ for $10 \mathrm{~h}$. The material thus obtained was designated as $\mathrm{ZH}_{3}$. Further calcination of $\mathrm{ZH}_{3}$ was carried out at $300^{\circ} \mathrm{C}$ and $500^{\circ} \mathrm{C}$ in air for $5 \mathrm{~h}$ and the resulting samples were designated as $\mathrm{ZH}_{33}$ and $\mathrm{ZH}_{35}$, respectively.

\subsection{Characterization}

The test for leaching of HPA from the surface of the support was carried out to check the chemical stability of the catalysts.

The FTIR spectra of the samples were obtained by using $\mathrm{KBr}$ wafer on Perkin-Elmer. The DRS spectra of samples were recorded on a Jasco DR-UV-VIS spectrophotometer (model V-550) instrument using barium sulphate as a reference. The XRD pattern was obtained using PW3040/ 60 X'pert PRO console. The condition used was: $\mathrm{CuK} \alpha$ radiation $(1.5417 \AA)$. The specific surface area was calculated using BET method from adsorption-desorption isotherm on Micromeritics ASAP 2010 surface area analyser. The surface morphology of the support and supported HPAs was studied by SEM. Scanning electron micrographs of $\mathrm{Z}, \mathrm{ZH}_{3}, \mathrm{ZH}_{33}$ and $\mathrm{ZH}_{35}$ were taken on a Jeol SEM instrument (model JSM-5610 LV) with a scanning electron electrode at $15 \mathrm{kV}$. Scanning was done at $1 \mathrm{~mm}$ range and images taken at a magnification of $100 \times, 500 \times$ and of single particle at $500 \times$. Particle size distribution of all materials was determined using a Malvern particle size analyser, Mastersizer 2000. The acidity of $\mathrm{Z}, \mathrm{ZH}_{3}$, $\mathrm{ZH}_{33}$ and $\mathrm{ZH}_{35}$ was determined by carrying out chemisorption of ammonia and esterification reactions.

\subsection{Acidity measurements}

2.4a Chemisorption of ammonia: The chemisorption of ammonia gas (pure) on the surface of the samples was carried out using Micromeritics Pulse Chemisorb-2705 instrument. The samples, prepared by heating at pre determined temperature, were kept in a U-shaped quartz and the tube was placed in a split furnace. The samples were first heated in situ at $300^{\circ} \mathrm{C}$ in flowing argon $(99.95 \%)$ for $2 \mathrm{~h}$ to remove moisture. The chemisorption of pure ammonia on the preheated samples was carried out at $120^{\circ} \mathrm{C}$ by repeatedly injecting a pulse of pure ammonia gas till saturation was observed. The amount of ammonia chemisorbed on the sample in every pulse was detected by a thermal conductivity detector (TCD) in the form of an integrated area of the ammonia peak. From the peak areas, the acidity in terms of mmoles of ammonia chemisorbed per gram of samples were calculated at $120^{\circ} \mathrm{C}$ for various preheated samples. The temperature of $120^{\circ} \mathrm{C}$ was selected for the adsorption studies to avoid physical adsorption of ammonia. 
2.4b Esterification reactions: The esterification of $1^{\circ}$ alcohol ( $n$-butanol) with formic acid, acetic acid and propionic acid was carried out in a round bottom flask provided with a double-walled condenser containing catalyst, $n$-butanol ( 1 mole) and corresponding acid ( 2 mole) at $80^{\circ} \mathrm{C}$ with stirring for $4 \mathrm{~h}$. For esterification of $2^{\circ}$ alcohol, cyclohexanol, isobutanol (1 mole) and acetic acid (3 mole) were taken and catalyst was then added in the required amount. Reaction was carried out at $80^{\circ} \mathrm{C}$ with stirring for $4 \mathrm{~h}$. The percentage of ester formation was determined on a Nucon Gas Chromatograph using Carbowax 20 column.

\section{Results and discussion}

Any leaching of the catalyst from the support makes the catalyst unattractive for reuse. So it is necessary to study the stability of HPA onto hydrous zirconia as well as leaching of HPA from the support in order to reuse the catalyst. HPA can be quantitatively characterized by the heteropoly blue colour, that is observed when it reacted with a mild reducing agent such as ascorbic acid (Yadav and Bokade 1996). In the present study, this method was used for determining the leaching of HPA from the support.
Standard samples containing $1-5 \%$ of 12-tungstophosphoric acid in water were prepared. To $10 \mathrm{ml}$ of the above samples, $1 \mathrm{ml}$ of $10 \%$ ascorbic acid was added. The mixture was diluted to $25 \mathrm{ml}$. The resultant solution was scanned at a $\lambda_{\max }$ of $785 \mathrm{~cm}^{-1}$ for its absorbance values. A standard calibration curve was obtained by plotting values of absorbance with percentage solution. $1 \mathrm{~g}$ of supported catalyst with $10 \mathrm{ml}$ conductivity water was refluxed for $4 \mathrm{~h}$. Then $1 \mathrm{ml}$ of the supernatant solution was treated with $10 \%$ ascorbic acid. Development of blue colour was not observed indicating that there was no leaching. The same procedure was repeated with $n$ butanol, cyclohexanol, isobutanol, formic acid, acetic acid, propionic acid and the filtrate of the reaction mixture after completion of reaction in order to check the presence of any leached 12-tungstophosphoric acid. The development of blue colour was not observed indicating absence of leaching of 12-tungstophosphoric acid. The above studies indicate the presence of chemical interaction between the HPA and the support. It also confirms the stability of catalysts under reaction conditions.

The frequencies of absorption bands of FTIR (figure 1) are reported in table 1 and are in good agreement with
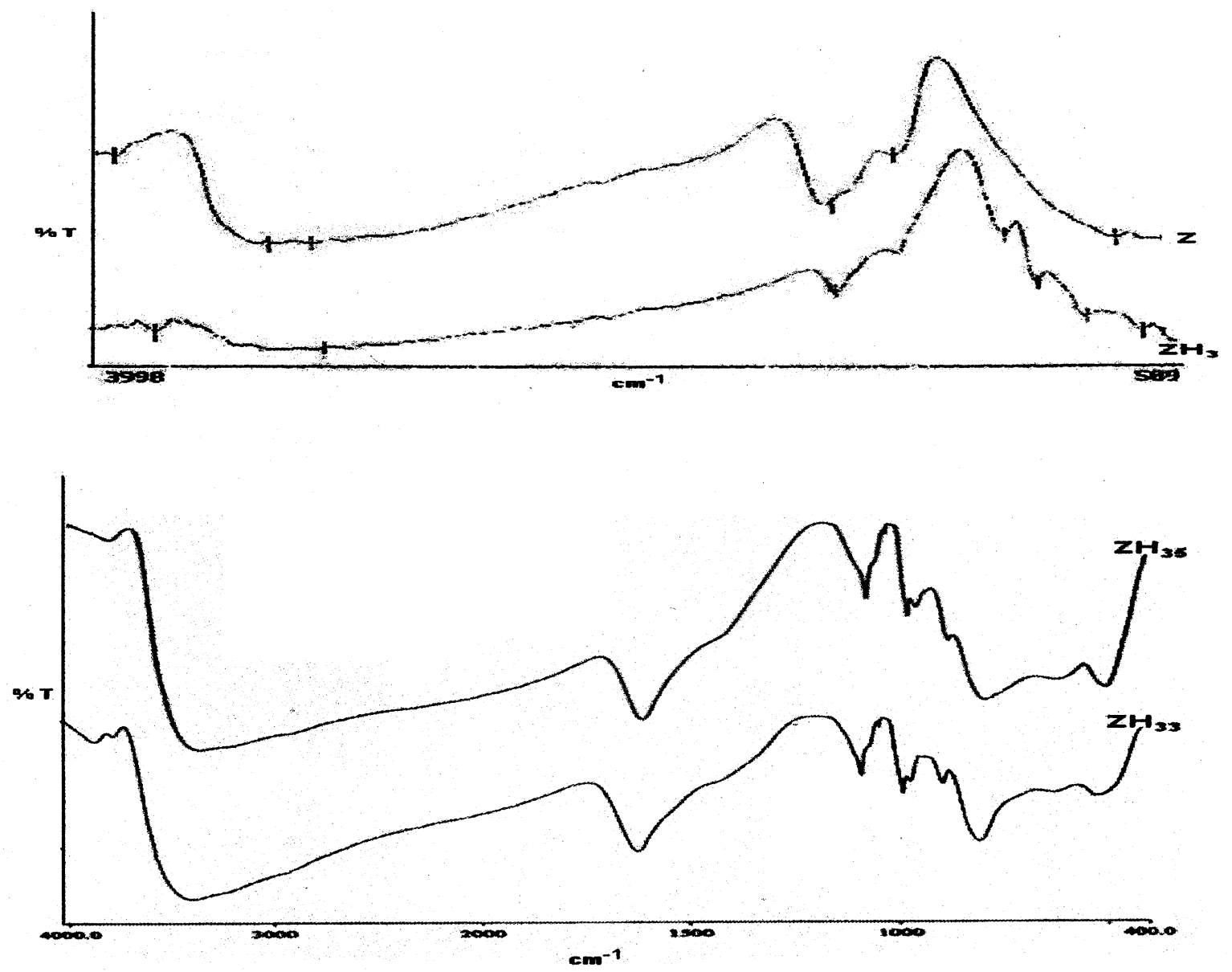

Figure 1. FT-IR of $\mathrm{Z}, \mathrm{ZH}_{3}, \mathrm{ZH}_{33}$ and $\mathrm{ZH}_{35}$. (Z: support (hydrous zirconia); $\mathrm{ZH}_{3}$ : catalyst prepared by $30 \%$ loading of 12-tungstophosphoric acid; $\mathrm{ZH}_{33}$ : catalyst $\mathrm{ZH}_{3}$ calcinated at $300^{\circ} \mathrm{C}$ for $5 \mathrm{~h} ; \mathrm{ZH}_{35}$ : catalyst $\mathrm{ZH}_{3}$ calcinated at $500^{\circ} \mathrm{C}$ for $5 \mathrm{~h}$ ). 
Table 1. Experimental absorption bands of supported catalysts and tentative band assignments.

\begin{tabular}{lccccccc}
\hline & \multicolumn{7}{c}{ Band frequency $\left(\mathrm{cm}^{-1}\right)$} \\
\cline { 2 - 8 } Catalyst & $\begin{array}{c}\text { Asym. hydroxo. } \\
\text { and aquo (OH) str. }\end{array}$ & H-O-H & O-H-O & Z-O-H & W-O-W & W=O & P-O \\
\hline $\mathrm{Z}$ & 3400 & 1600 & 1370 & 600 & - & - & - \\
$\mathrm{ZH}_{3}$ & 3400 & 1600 & 1370 & 600 & 1070 & 964 & 812 \\
$\mathrm{ZH}_{33}$ & 3400 & 1600 & 1370 & 600 & 1080 & 964 & 807 \\
$\mathrm{ZH}_{35}$ & 3400 & 1600 & 1370 & 600 & 1080 & 962 & 799 \\
\hline
\end{tabular}

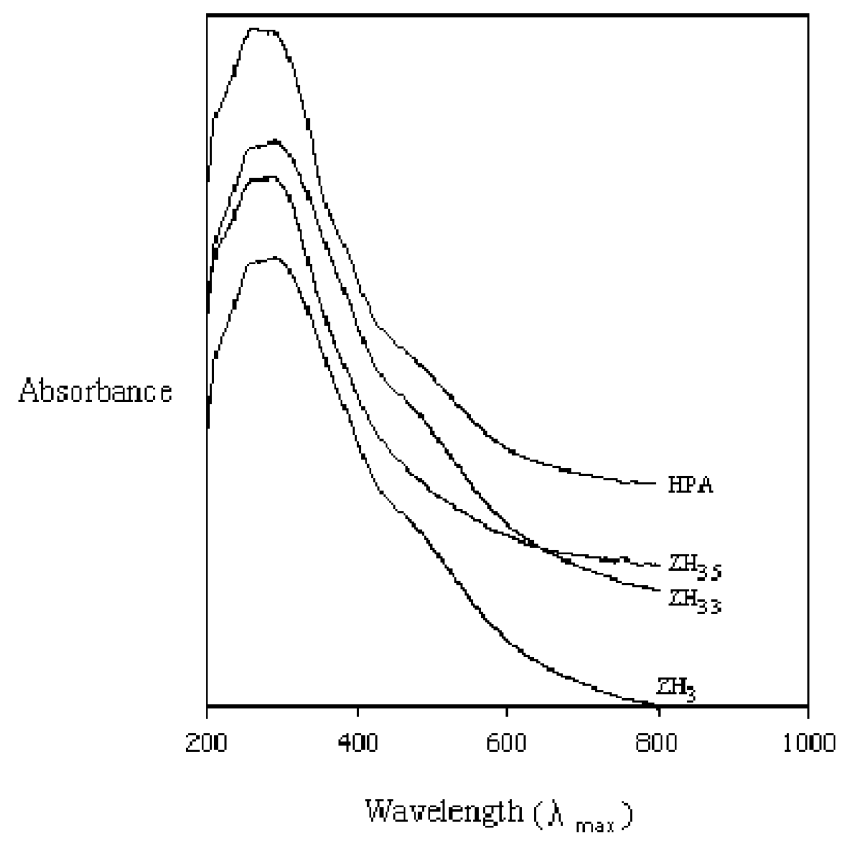

Figure 2. DRS of HPA, $\mathrm{ZH}_{3}, \mathrm{ZH}_{33}$ and $\mathrm{ZH}_{35}$. $\left(\mathrm{ZH}_{3}\right.$ : catalyst prepared by $30 \%$ loading of 12 -tungstophosphoric acid; $\mathrm{ZH}_{33}$ : catalyst $\mathrm{ZH}_{3}$ calcinated at $300^{\circ} \mathrm{C}$ for $5 \mathrm{~h} ; \mathrm{ZH}_{35}$ : catalyst $\mathrm{ZH}_{3}$ calcinated at $500^{\circ} \mathrm{C}$ for $5 \mathrm{~h}$; HPA: 12-tungstophosphoric acid).

those reported earlier (Okuhara et al 1996) confirming the presence of heteropolyanion in the prepared materials. The band at $1070 \mathrm{~cm}^{-1}$ does not appear to be split into components at $1085 \mathrm{~cm}^{-1}$ and $1040 \mathrm{~cm}^{-1}$ assigned to $\left[\mathrm{PW}_{11} \mathrm{O}_{39}\right]^{2-}$ ion. There is a slight shift in the FTIR bands of $\mathrm{ZH}_{33}$ and $\mathrm{ZH}_{35}$ as compared to that of $\mathrm{ZH}_{3}$. Thus FTIR study indicates that the 12-tungstophosphoric acid keeps its Keggin type structure up to $500^{\circ} \mathrm{C}$.

Electronic absorption spectra gives information about the non-reduced heteropolyanions due to ligand (oxygen) to metal charge transfer (Varga et al 1970). The DRS spectra of $\mathrm{ZH}_{3}, \mathrm{ZH}_{33}$ and $\mathrm{ZH}_{35}$ show $\lambda_{\max }$ at $260 \mathrm{~nm}$ (figure 2) which is in good agreement with the earlier reported data (Okuhara et al 1996) giving evidence for the presence of the undegraded $\mathrm{H}_{3} \mathrm{PW}_{12} \mathrm{O}_{40}$ species. In other words, the Keggin phase remains unaltered up to $500^{\circ} \mathrm{C}$.

The XRD of $\mathrm{Z}$ and $\mathrm{ZH}_{3}$ showed no crystalline structure indicating that the materials were amorphous. The XRD pattern of $\mathrm{ZH}_{3}$ also showed no diffraction lines of HPAs indicating a very high dispersion of solute in a noncrystalline form on the support surface. This is further supported by particle size distribution study. The graph showing average particle distribution for $\mathrm{Z}$ and $\mathrm{ZH}_{3}$ is given in figure 3 . It is seen from the figure that the graph (b) is more smoother as compared to graph (a). It is known that in case of particle size distribution, smoother graph contributes towards uniform distribution of particles. The graphs shown in the figure indicates that there is a non-uniform distribution of particles in case of $\mathrm{Z}$ and all particles fall in the range $1-200 \mu \mathrm{m}$ while for $\mathrm{ZH}_{3}$ uniform distribution of particles are found and all particles fall in the range $1-20 \mu \mathrm{m}$. The values (table 2) of specific surface area obtained from particle size distribution for $\mathrm{Z}$ and $\mathrm{ZH}_{3}$ are $0.206 \mathrm{~m}^{2} / \mathrm{g}$ and $2-28 \mathrm{~m}^{2} / \mathrm{g}$, respectively. It is well known that higher the particle size, lower is the specific surface area. The obtained values are in good agreement with this. The value of total surface area obtained from BET method (table 2) also has a similar trend i.e. the value of surface area of $\mathrm{ZH}_{3}$ (146) is less than that of $Z$ (170). Thus, significant decrease in average particle size diameter and increase in the specific surface area and total surface area may be due to the support of heteropolyacid as well as uniform dispersion of the heteropolyacid onto the surface of the support.

The SEM of $\mathrm{Z}$ and $\mathrm{ZH}_{3}$ are shown in figure 4. It is seen from the figure that the surface of the support is distinctly altered. SEM of $\mathrm{Z}$ (figure $4 \mathrm{a}$ ) shows a non-uniform distribution of particles. The SEM of $\mathrm{ZH}_{3}$ (figure $4 \mathrm{~b}$ ) shows a uniform distribution of particles and also significant reduction in particle size as compared to that of $\mathrm{Z}$. The reduction in particle size may be due to the support of heteropolyacid. Thus XRD, particle size distribution and SEM are in good agreement with each other and confirms the uniform and high dispersion of HPA in a non-crystalline form because of the interaction with the support on the support surface.

Table 2 shows the value of average particle size diameter, total acidity of materials and the value of percentage yield (\%) of different esters, butyl formate, butyl acetate, butyl propionate, cyclohexyl acetate and iso-butyl acetate. It is also seen from table 2 that the value of average particle size diameter is maximum for $\mathrm{ZH}_{35}$ i.e. the catalyst calcinated at $500^{\circ} \mathrm{C}$. The order of value of average parti- 


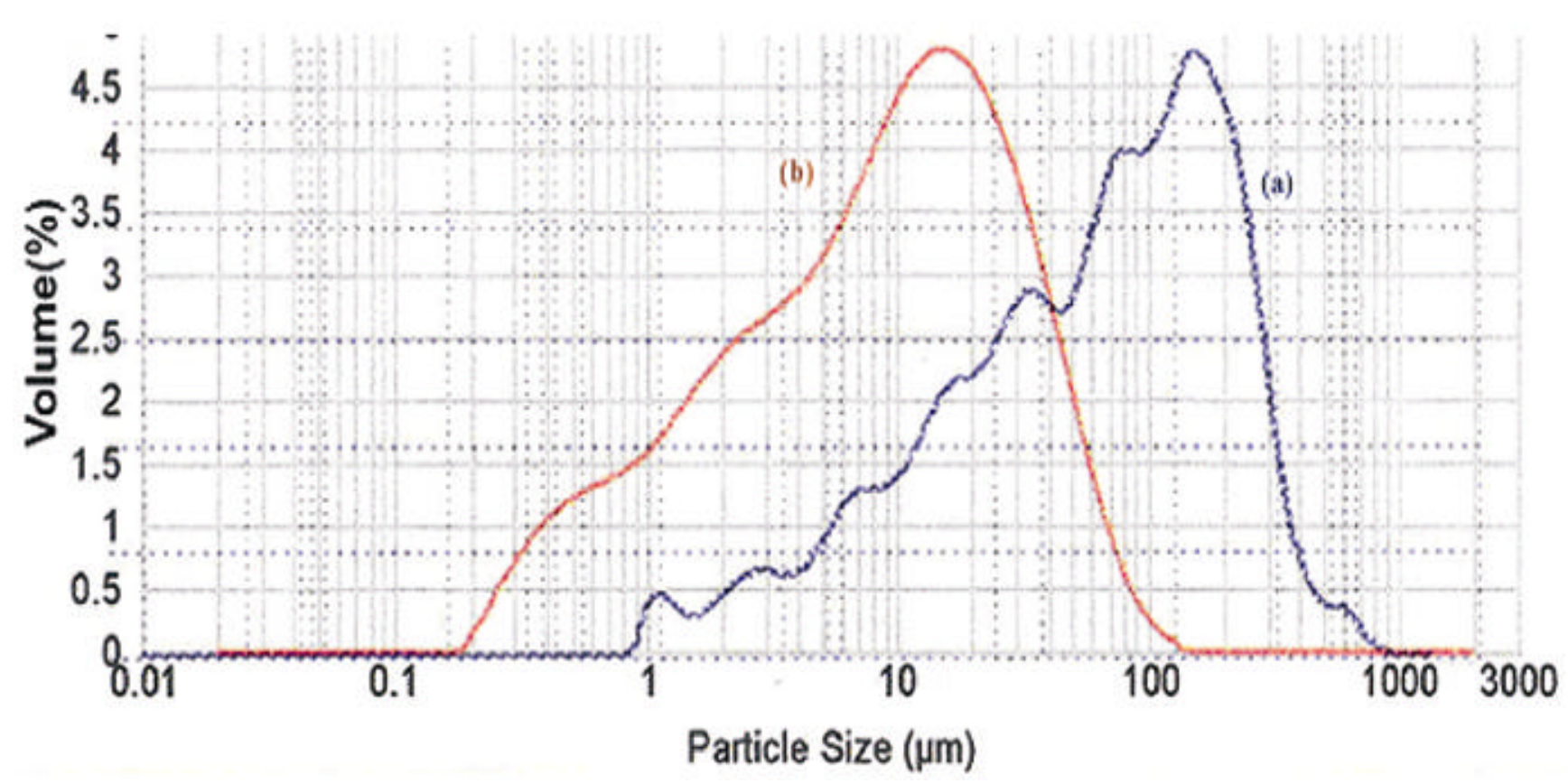

Figure 3. Average particle size distribution of (a) $\mathrm{Z}$ and (b) $\mathrm{ZH}_{3}$. (Z: support (hydrous zirconia); $\mathrm{ZH}_{3}$ : catalyst prepared by $30 \%$ loading of 12-tungstophosphoric acid).

Table 2. The values of surface area, average particle size diameter and total acidity and value of percentage yield (\%) of different esters: butyl formate, butyl acetate, butyl propionate and cyclohexyl acetate.

\begin{tabular}{|c|c|c|c|c|c|c|c|c|c|}
\hline Catalyst & $\begin{array}{l}\% \text { Yield } \\
\text { of butyl } \\
\text { formate }^{\mathrm{a}}\end{array}$ & $\begin{array}{l}\% \text { Yield } \\
\text { of butyl } \\
\text { acetate }^{a}\end{array}$ & $\begin{array}{c}\% \text { Yield } \\
\text { of butyl } \\
\text { propionate }^{\mathrm{a}}\end{array}$ & $\begin{array}{l}\% \text { Yield of } \\
\text { isobutyl } \\
\text { acetate }^{\mathrm{a}}\end{array}$ & $\begin{array}{l}\% \text { Yield of } \\
\text { cyclohexyl } \\
\text { acetate }^{\mathrm{b}}\end{array}$ & $\begin{array}{c}\text { Total } \\
\text { surface area } \\
\left(\mathrm{m}^{2} / \mathrm{g}\right)\end{array}$ & $\begin{array}{c}\text { Total acidity } \\
\text { (mmol. of } \\
\mathrm{NH}_{3} / \mathrm{g} \text { sample) }\end{array}$ & $\begin{array}{c}\text { Average } \\
\text { particle size } \\
\text { diameter }(\mu \mathrm{m})\end{array}$ & $\begin{array}{c}\text { Specific } \\
\text { surface } \\
\text { area }\left(\mathrm{m}^{2} / \mathrm{g}\right)\end{array}$ \\
\hline Z & 52 & 51 & 27 & 46 & 38 & 170 & 0.64 & $112 \cdot 15$ & $0 \cdot 206$ \\
\hline $\mathrm{ZH}_{3}$ & 75 & 70 & 47 & 73 & 68 & 146 & 0.84 & $9 \cdot 12$ & $2 \cdot 28$ \\
\hline $\mathrm{ZH}_{33}$ & 75 & 71 & 46 & 77 & 78 & 214 & 1.06 & $16 \cdot 90$ & $2 \cdot 32$ \\
\hline $\mathrm{ZH}_{35}$ & 84 & 78 & 48 & 81 & 84 & 126 & $1 \cdot 24$ & $22 \cdot 16$ & 1.68 \\
\hline
\end{tabular}

Amount of catalyst, $0.5 \mathrm{~g}$; ${ }^{\mathrm{a}}$ mole ratio of alcohol to acid is $1: 2 ;{ }^{\mathrm{b}}$ mole ratio of alcohol to acid is $1: 3$.

cle size diameter $\mathrm{ZH}_{35}>\mathrm{ZH}_{33}>\mathrm{ZH}_{3}$ can be explained as follows.

It is well known that the structure of hydrous zirconia (Clearfield 1988) is open containing water molecules in the form of $\mathrm{OH}^{-}, \mathrm{H}_{3} \mathrm{O}^{+}$and $\mathrm{H}_{2} \mathrm{O}$. It is also known that the structure of HPA contains unbonded $\mathrm{H}_{2} \mathrm{O}$ molecules as water of crystallization inside the cages of HPA. Increase in the particle size of $\mathrm{ZH}_{33}$ may be due to the loss of $\mathrm{H}_{2} \mathrm{O} / \mathrm{H}_{3} \mathrm{O}^{+}$from hydrous zirconia as well as loss of crystalline $\mathrm{H}_{2} \mathrm{O}$ from the structure of heteropolyanion by expanding the lattice. This loss takes place without any major change in the structure of supported heteropolyanion and is in good agreement with our earlier results (Sharma et al 2004). On strong heating, i.e. calcination at $500^{\circ} \mathrm{C}$, the total removal of $\mathrm{H}_{2} \mathrm{O} / \mathrm{H}_{3} \mathrm{O}^{+}$from hydrous zirconia is expected and hence more expansion of lattice is also expected. This may be the reason for $\mathrm{ZH}_{35}$ to have maximum average particle size diameter. These observations can be very well shown in the SEM of $\mathrm{ZH}_{3}, \mathrm{ZH}_{33}$ and $\mathrm{ZH}_{35}$. The SEM of $\mathrm{ZH}_{3}, \mathrm{ZH}_{33}$ and $\mathrm{ZH}_{35}$ are also shown in figures 5 and 6 . The SEM of $\mathrm{ZH}_{35}$ appears more shining and somewhat crystalline among all as a result of total removal of $\mathrm{H}_{2} \mathrm{O} / \mathrm{H}_{3} \mathrm{O}^{+}$from hydrous zirconia.

The XRD of $\mathrm{ZH}_{33}$ and $\mathrm{ZH}_{35}$ is shown in figure 7. The XRD pattern of $\mathrm{ZH}_{35}$ indicates the presence of crystalline entities. It shows the characteristic diffraction line for tetragonal zirconia. These changes may be due to complete loss of water molecules present in the form of $\mathrm{OH}^{-}$, $\mathrm{H}_{3} \mathrm{O}^{+}$and $\mathrm{H}_{2} \mathrm{O}$ from hydrous zirconia after calcination $\left(500^{\circ} \mathrm{C}\right)$. The absence of characteristic diffraction line of 12-tungstophosphoric acid indicates undegraded species of HPA onto the surface of the support.

\subsection{Acidity}

The total acidity of the support, catalysts and \% yields of different esters are shown in table 2. 

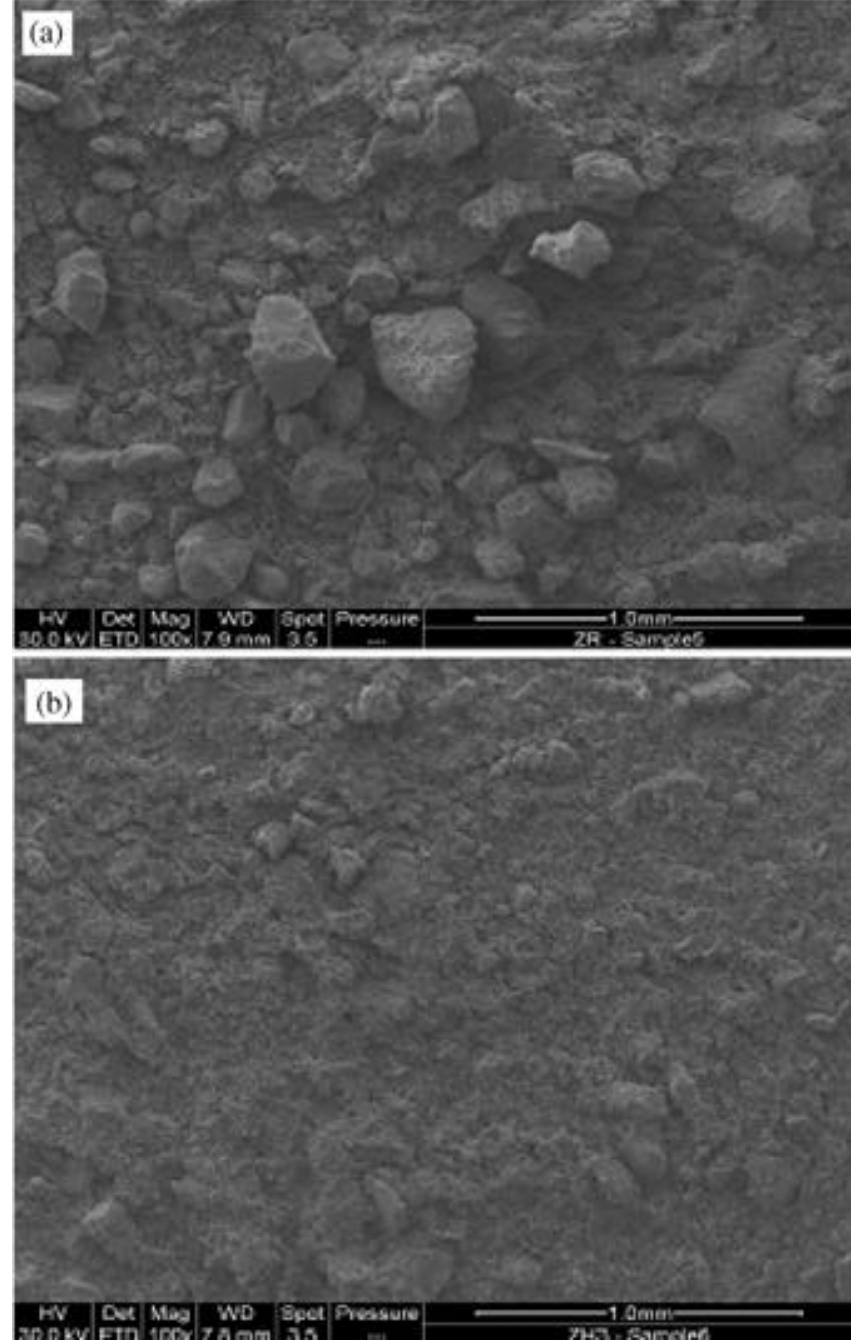

Figure 4. SEM of (a) Z (support, hydrous zirconia) and (b) $\mathrm{ZH}_{3}$ (catalyst prepared by $30 \%$ loading of 12-tungstophosphoric acid).

The esterification is a straight forward reaction subject to general Bronsted acid catalysis. The yield can be increased by increasing the concentration of either alcohol or acid (Furnis et al 1994). In a practical situation when one wants to prepare an ester, it is desirable to obtain the maximum yield. For economic reasons the reactant that is usually less expensive of the two is taken in excess. In the present study, all corresponding acids were used in excess.

The $\%$ yield of above three esters are obtained in the following order:

Butyl formate $>$ butyl acetate $>$ butyl propionate.

The $\%$ yield can be explained on the basis of the size of reacting acids. As the size/bulkiness of the acid increases, the number of acid molecules sorbed on the surface of the catalyst will decrease and hence the number of molecules reacting in definite time will be less. This should result in decrease in the amount of the product. In case of formic acid the $\%$ yield of the ester is higher compared to the
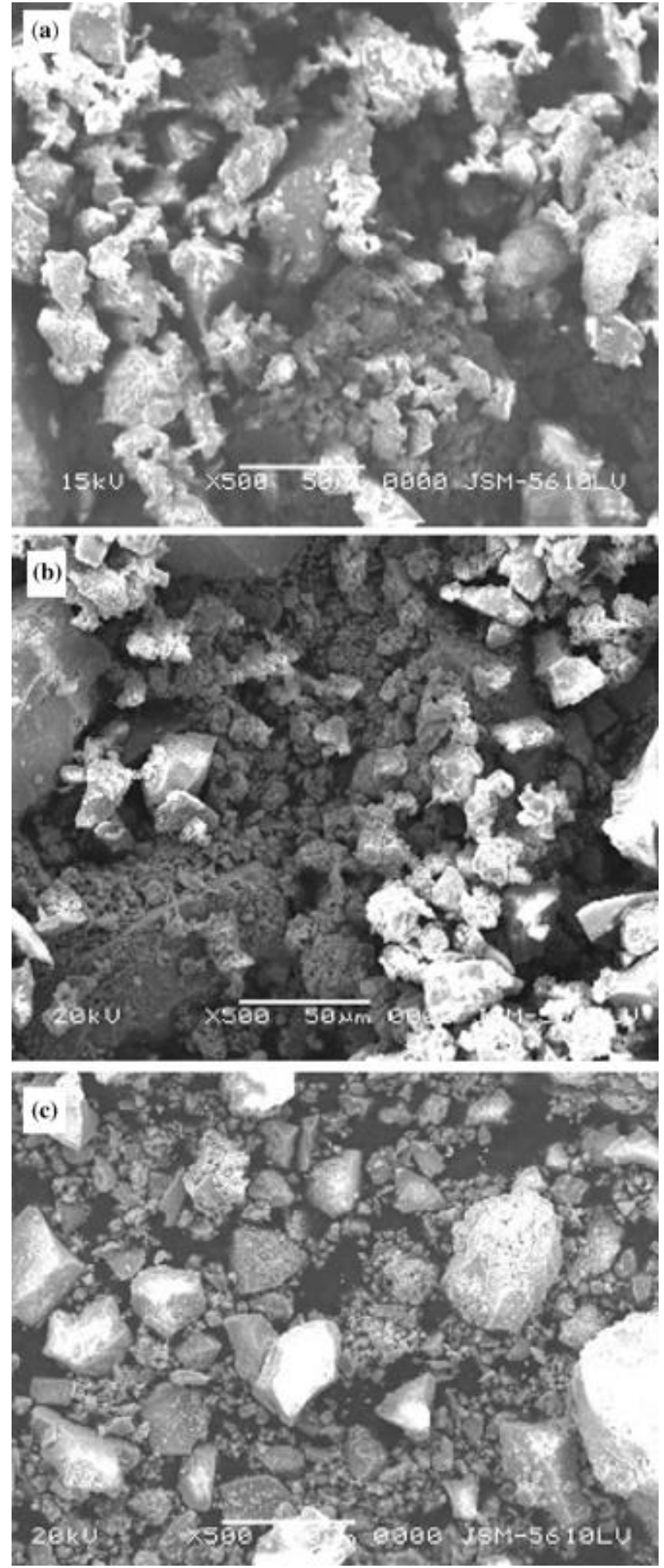

Figure 5. SEM of (a) $\mathrm{ZH}_{3}$ (catalyst prepared by $30 \%$ loading of 12-tungstophosphoric acid $(\times 500)$, (b) $\mathrm{ZH}_{33}$ (catalyst $\mathrm{ZH}_{3}$ calcinated at $300^{\circ} \mathrm{C}$ for $5 \mathrm{~h}$ ) and (c) $\mathrm{ZH}_{35}$ (catalyst $\mathrm{ZH}_{3}$ calcinated at $500^{\circ} \mathrm{C}$ for $5 \mathrm{~h}$ ).

acetic acid and propionic acid. The presence of $-\mathrm{CH}_{3}$ and $-\mathrm{C}_{2} \mathrm{H}_{5}$ groups in the latter two acids results in the decrease in the yield. 

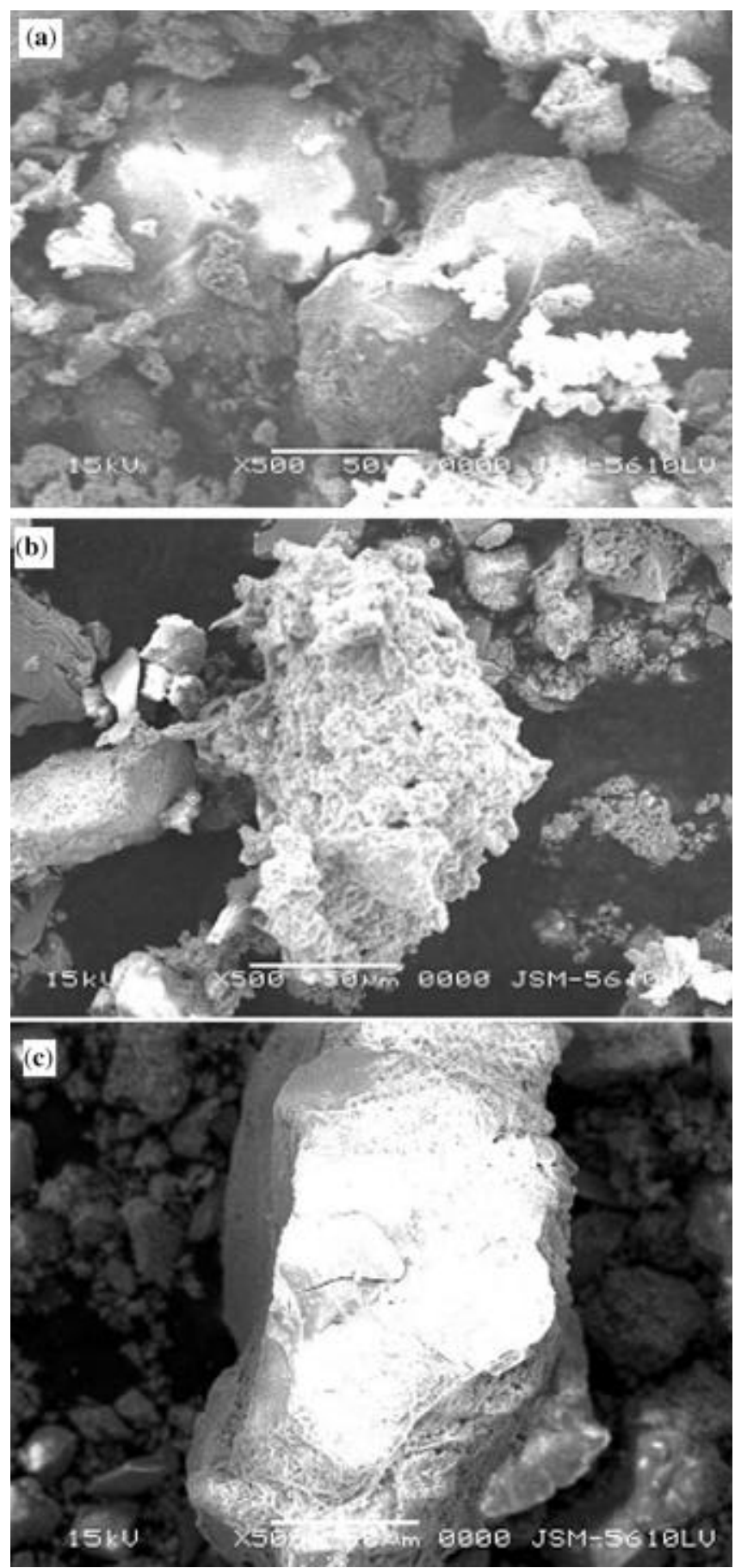

Figure 6. SEM of single particle of (a) $\mathrm{ZH}_{3}$ (catalyst prepared by $30 \%$ loading of 12-tungstophosphoric acid), (b) $\mathrm{ZH}_{33}$ (catalyst $\mathrm{ZH}_{3}$ calcinated at $300^{\circ} \mathrm{C}$ for $5 \mathrm{~h}$ ) and (c) $\mathrm{ZH}_{35}$ (catalyst $\mathrm{ZH}_{3}$ calcinated at $500^{\circ} \mathrm{C}$ for $\left.5 \mathrm{~h}\right)(\times 500)$.

It is seen from table 2 that $\mathrm{ZH}_{35}$ has the highest total acidity. On heating $\left(\mathrm{ZH}_{33}\right.$ and $\left.\mathrm{ZH}_{35}\right)$ there may be increase of Lewis acidity on $\mathrm{Z}$ which results in an increase in the total acidity. It is also seen from table 2 that the increase in $\%$ yield of esters is not comparable with increase in total acidity. This may be due to the fact that esterification
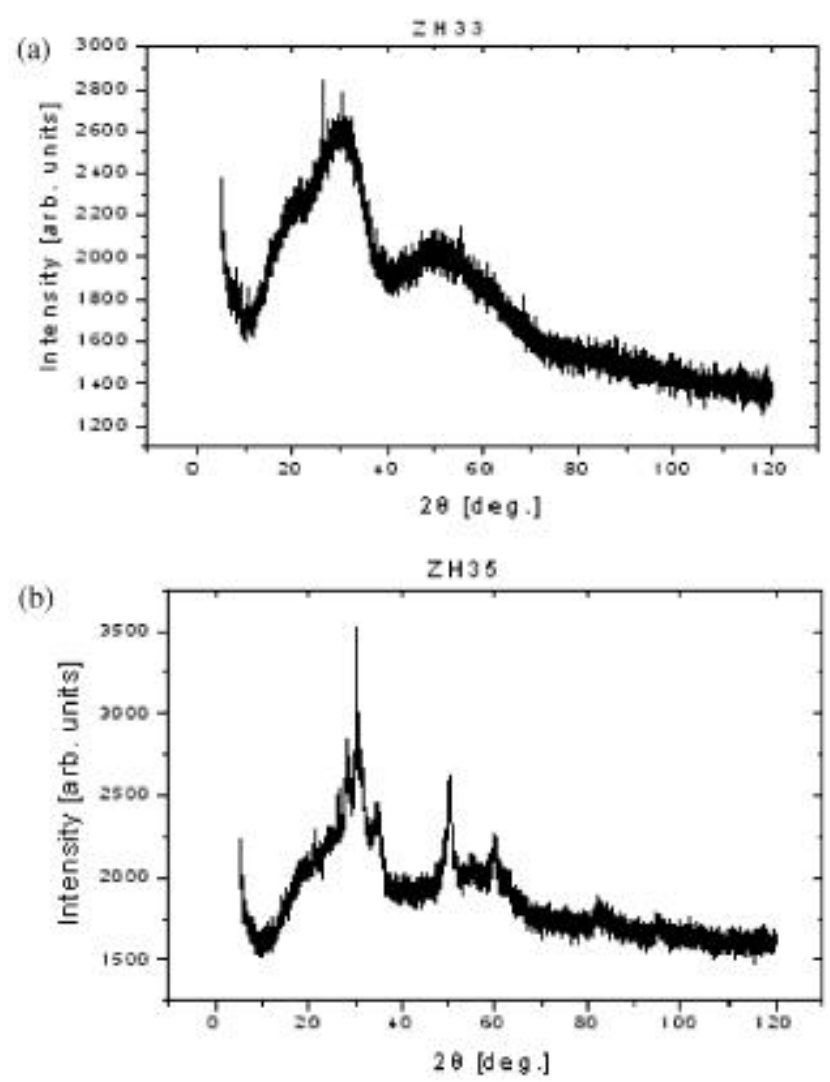

Figure 7. $\mathrm{XRD}$ of (a) $\mathrm{ZH}_{33}$ and (b) $\mathrm{ZH}_{35}$. $\left(\mathrm{ZH}_{33}\right.$ : catalyst $\mathrm{ZH}_{3}$ calcinated at $300^{\circ} \mathrm{C}$ for $5 \mathrm{~h} ; \mathrm{ZH}_{35}$ : catalyst $\mathrm{ZH}_{3}$ calcinated at $500^{\circ} \mathrm{C}$ for $5 \mathrm{~h}$ ).

reactions are mainly catalysed by Bronsted acidity. It is also observed that the catalyst $\left(\mathrm{ZH}_{35}\right)$ consisting of highest total acidity gives maximum yield of esters. The optimized conditions for present reactions are: amount of the catalyst $(0 \cdot 5 \mathrm{~g})$, refluxing temperature $\left(80^{\circ} \mathrm{C}\right)$ and reaction time (4 h).

The catalyst $\left(\mathrm{ZH}_{35}\right)$ was washed with conductivity water and dried at $100^{\circ} \mathrm{C}$ and reused. In the regenerated sample the yield decreased by $5 \%$. The yield becomes constant on further regeneration. The catalyst, $\mathrm{ZH}_{35}$, has several advantages as a solid acid catalyst for liquid-phase reactions since it is insoluble, easily reusable and thermally more stable. Further it can be used in various types of acid catalysed liquid-phase organic reactions over a wide temperature range $\left(500^{\circ} \mathrm{C}\right)$. They are environmentally friendly candidates by which conventional problematic corrosive acid catalysts can be replaced.

\section{Conclusions}

FTIR and DRS studies confirm the undegraded HPA supported onto the surface of the support up to $500^{\circ} \mathrm{C}$. XRD, SEM and average particle size distribution show that the 
morphology of the support, Z, is distinctly altered, exhibit considerable shining after supporting of HPA. It shows significant reduction of the particle size as well as uniform distribution of particles for $\mathrm{ZH}_{3}$. It also indicates that the species present onto the supported surface are highly dispersed as a non-crystalline form and after calcination at $500^{\circ} \mathrm{C}$, formation of crystalline phase, probably conversion of hydrous zirconia to zirconia takes place. It was found that the catalyst calcinated at $500^{\circ} \mathrm{C}, \mathrm{ZH}_{35}$, has the highest average particle size, highest acidity, highest \% yield for all esters and hence is best among all. The catalytic activity of the catalyst correlated well with the total acidity. It can be concluded that the present catalyst is not a surface type ordinary heterogeneous catalyst in which catalytic activity is directly proportional to the surface area of the catalyst, but it is pseudoliquid-bulk I type catalyst in which the catalytic activity is directly proportional to the total acidity of the catalyst.

\section{Acknowledgements}

We are thankful to Dr B S Chakraborty, Applied Physics Department and Prof. R S R Murthy, Pharmacy Department, Faculty of Technology and Engineering, M.S. University of Baroda, Vadodara, for carrying out calcinations and particle size distribution, respectively. We are also thankful to Dr R V Jasra, CSMCRI, Bhavnagar, for carrying out surface area measurements. One of the authors (PS) is thankful to UGC, New Delhi, for financial assistance.

\section{References}

Bielanski A, Lubanska A, Pozniczek J and Iiinicka A M 2003a Appl. Catal. A238 239

Bielanski A, Lubanska A, Pozniczek J and Iiinicka A M 2003b Appl. Catal. A256 153

Blasco T, Corma A, Martinez A and Martinez-Escolano P 1998 J. Catal. 177306

Choi S, Wang Y, Nie Z, Liu J and Pedas C H F 2000 Catal. Today $\mathbf{5 5} 117$

Chu W, Zhao Z, Sun W, Ye X and Wu Y 1998 Catal. Lett. 5557

Clark J H, Kybett A P and Macquarrie D J 1992 in Supported reagents: Preparation, analysis and applications (New York: VCH Publishers)

Clearfield A 1988 Chem. Rev. 88125

Damyanova J and Fierro L G 1998 Chem. Mater. 10871

Damyanova S, Dimitrov L, Mariscal R, Fierro L G, Petrov L and Sobrados I 2003 Appl. Catal. A256 183

Deltcheff C R, Amirouche M, Herve G, Fournier M, Che M and Tatibouet J M 1990 J. Catal. 126591

Dupont P and Lefebve F 1996 J. Mol. Catal. A124 299

Dupont P, Vedrine J C, Paumard E, Hecquet G and Lefebve F 1995 Appl. Catal. A129 217

Dutenhefner P A R, daSilva K A, Siddiqui M H, Kozhevnikov I V and Gusevskaya E V 2001 J. Mol. Catal. A175 33
Faming Z, Shuoming Shu and Shenquing G CN 1. 197. 057 (CI. C 07 C 69/34) 28 Oct. 1998 Appl. 97, 104, 06123 Apr. 1997; $6 \mathrm{pp}$ (Ch.)

Furnis B S, Hannaford A J, Rogers V, Smith P W G and Talohal A R 1994 Textbook of practical organic chemistry including qualitative organic analysis (New York: Longman), Ch. 3, 4th ed.

Gao S and Moffat J B 2002 Appl. Catal. A229 245

Haber J, Pamin K, Matachowski L and Mucha D 2003 Appl. Catal. A256 141

Hill C L and Posser-Mc Carthy C M 1995 Coord. Chem. Rev. 143407

Hu Y Z, Xu L and Peng G 1999 Appl. Catal. A177 237

Ivanov A V, Zausa E, Taarit Y B and Essayem N 2003 Appl. Catal. A256 225

Izumi Y, Hasebe R and Urabe K 1983 J. Catal. 84402

Izumi Y, Urabe K and Onaka M 1992 Zeolites clay and heteropolyacid in organic reactions (Tokyo: Kodansha) Vol. 99

Jalil P A, Al-Daous M A, Al-Afraj A R A, Al-Amer A M, Beltramini J and Barri S A I 2001 Appl. Catal. A207 159

Knifton J F and Edwards J C 1999 Appl. Catal. $\mathbf{A 1 8 3} 1$

Kozhevnikov I V 1987 Russ. Chem. Rev. 56811

Kozhevnikov I V 1994 Stud. Surf. Sci. Catal. 2190

Kozhevnikov I V 1995 Catal. Rev. Sci. Eng. 37311

Kozhevnikov I V and Matveev K I 1983 Appl. Catal. A5 135

Kozhevnikov I V, Sinnema A, Jansen R J, Panin K and Bekkum K V 1995 Catal. Lett. 30241

Kozhevnikov I V, Holmes S and Siddiqui M H 2001 Appl. Catal. A214 47

Misono M 1987 Catal. Rev. Sci. Eng. 29269

Misono M 1998 Rev. Sci. Eng. 30339

Misono M and Nojiri N 1990 Appl. Catal. A64 1

Misono M, Mizuno N, Katamura K, Kasai A, Konishi Y, Sakata K, Okuhara T and Yoneda Y 1982 Bull. Chem. Soc. Jpn 5557

Mizuno N and Misono M 1998 Chem. Rev. 98198

Molnar A, Keresszegi C and Torok B 1999 Appl. Catal. A189 217

Mukai S R, Sugiyama T and Tamon H 2003 Appl. Catal. $\mathbf{2 5 6} 99$

Nomiya K, Murasaki H and Miwa M 1986 Polyhedron 51031

Nowinska C, Fiedorow R and Adamiec J 1991 J. Chem. Soc. Faraday Trans. 87749

Nowinska K, Formaniak R, Kateta W and Waclaw A 2003 Appl. Catal. A256 115

Okuhara T 2003 Appl. Catal. A256 213

Okuhara T, Hu C, Hashimoto M and Misono M 1994 Bull. Chem. Soc. Jpn 671186

Okuhara T, Mizuno N and Misono M 1996 Adv. Catal. 41113

Patel S, Purohit N and Patel A 2003 J. Mol. Catal. A192 195

Pizzio L R, Cacares C V and Blanco M N 1998 Appl. Catal. A167 283

Pizzio L R, Vazquez P G, Caceres C V and Blanco M N 2003 Appl. Catal. A256 125

Pope M T 1983 Heteropolyacid and isopolyoxometallates (Berlin: Springer Verlag)

Rocchiccioli-Deltcheff C, Amirouche M, Herve G, Fournier M, Che M and Tatibouet J M 1990 J. Catal. 126591

Schwegler M A, Vinke P and Bekkum M V 1990 Appl. Catal. A80 41

Schwegler M A, Vinke P, Vijk M and Bekkum H 1992 Appl. Catal. A80 41

Sharma P, Vyas S and Patel A 2004 J. Mol. Catal. A214 281 
Siahkali A G, Philippou A, Dwyer J and Anderson M W 2000 Appl. Catal. A192 57

Swanml S, Shin-ichi N, Okuhara T and Misono M $1997 \mathrm{~J}$. Catal. 166263

Tatibouet J M, Montalescot C, Bruckman K, Haber J and Che M 1997 J. Catal. 16922

Varga G M, Papaconstantious E and Pope M T 1970 Inorg. Chem. 9667

Vazquez P G, Blanco M N and Caceres C V 1999 Catal. Lett. 60205
Verhoef M J, Kooyamann P J, Peters J A and Bekkum Van 1999 Microporous Mesoporous Mater. 27365

Wu Y, Ye X, Yang X, Wang X, Chu W and Hu Y 1996 Ind. Eng. Chem. Res. 352546

Yadav G D and Bokade V V 1996 Appl. Catal. A147 299

Yadav G D and Kirthivasan N 1997 Appl. Catal. A154 29

Yadav G D and Doshi N S 2000 Catal. Today 60263

Yadav G D and Doshi N S 2002 Appl. Catal. A236 129

Yadav G D, Pujari A A and Joshi A V 1999 Green Chem. 1269 